\title{
INSTITUTIONAL CHANGES IN STATE AUTHORITIES COLLABORATING WITH NGOS
}

This article focuses on recent changes in the practices of state and municipal authorities when collaborating with NGOs on various state-driven developmental initiatives, from national projects and federal programs to smaller-scale regional programs. There is a consensus in the civil society literature that a two-track state policy towards NGOs has emerged: repressive measures toward 'political' NGOs are combined with support and encouragement for 'sociallyorientted' NGOs (SO NGOs). The focus in this article is on SO NGOs and offers an analysis of new trends in state-NGO interactions. As certain functions, authorities, and responsibilities from the state agencies have been transferred to NGOs (SO NGOs), the action patterns, organisational structures, values and norms on the both sides have also evolved. On the one hand, the authorities express willingness to take measures and give NGOs new powers in the implementation of social policy. On the other hand, there are also concerns about procedural and, sometimes, values-related mismatches between the authorities and SONGOs. The article is based on expert interviews with three groups of actors in Nizhny Novgorod Oblast: the regional and municipal authorities; entrepreneurs; and representatives of SO NGOs. What is found is that a shift in values is noticeable. Some NGOs are potentially interested in gaining the status of 'socially oriented' and, consequently, funding and support for their activities. At the same time, they face difficulties adjusting to the demands of the authorities. Therefore, organisations of both types (NGOs and state agencies) must make mutual adjustments in terms of practices and values.

Keywords: state, NGO, social institutions, social policy

DOI: 10.17323/727-0634-2020-18-3-523-538

Alexander Soldatkin-Cand. Sci. (Soc.), Associate Professor, Faculty of Social Sciences, Lobachevsly State University, Nizhny Novgorod, Russian Federation. Email: alexander.soldatkin@gmail.com

Matthew Blackburn - PhD in Russian Studies (University of Glasgow); Postdoc, Institute of Russian and Eurasian Studies, Uppsala University, Sweden. Email: matthew.blackburn@btinternet.com 


\section{Introduction. The State-NGO relationship in Russia over the past three decades}

One of the central pillars in Russia's envisioned transition out of communism towards democracy and the free market was a radical change in the role of institutions. In the 1990s, non-governmental organisations were expected to play a central transformative role. Thus, they were largely given free rein in their operations; the Yeltsin era can be viewed as one of 'benevolent non-interference' on part of state (Benevolenski, Toepler 2017:65). On the other hand, the period was one in which shock therapy economics and corruption stopped institutions from playing the legitimate independent roles necessary for a successful transition (Puffer et al. 2016:26-27). By the end of the 1990s, instead of a 'successful grassroots NGO movement', Russia ended up with a 'small, isolated and elitist community of professional advocacy NGOs who focused on campaigns and issues more likely to appeal to their Western donors than their domestic constituents' (Bindman 2015:343; see, also Hemment 2012). Soviet legacies and serious socio-economic dislocation left Western-dependent NGOs in a 'holding pattern', struggling to stay in existence (Sundstrom, Henry 2006). Overall, there is consensus in the literature that NGOs in Russia fell far short of their potential impact in developing civil society, and were neither able to act as a restraint on the state nor encourage public participation in civic affairs (Ljubownikow, Crotty 2013: 6).

Putin's second term as president brought with it the passing of a new NGO law (Federal Law 2006) that placed a variety of restrictions and oversights on their activities, especially in response to the so-called 'colour revolutions' in Georgia (2003), Ukraine (2004) and Kyrgyzstan (2005). This led to a drop in NGO funding from abroad and a fall in the number of voluntary organisations (Sätre 2014: 524), leading many observers to conclude that civil society in Russia was being subordinated to the state as Putin pursued a 'top-down' model of state-society relationship. It was argued Russia has a 'statist' civil society, one where the state plays 'a dominant, directing and all-encompassing role with regard to civil society formation and development' (Ljubownikow, Crotty 2013: 15). In this statist model, it can be argued Russia suffers from an 'institutional void'; where institutions lacking legitimacy and genuine independence are bypassed by a powerful state in ways that stop Russia enjoying the kind of transition experienced, for example, by Poland (Puffer et al. 2016:27). Civil society, if understood as an agent in construction of democracy, was clearly not operational in Putin's Russia, leading some observers to see Russia as sliding into authoritarianism and civil society disappearing (Crotty et al. 2014).

This view, however, is only part of the story. While foreign-funded NGOs dealing with politically sensitive areas have suffered greatly in the Putin years, if we look at socially orientated NGOs (SO NGOs), the picture is very different. The SO NGOs were legally defined by a Federal Law (2010) as 'non- 
profit organisations $\langle\ldots\rangle$ (with the exception of state corporations, state companies, public associations that are political parties) $<\ldots>$ carrying out activities aimed at solving social problems, and developing civil society in the Russian Federation'. Later, in 2016, some of the SO NGOs were given the right to acquire the status of 'performing socially useful services' (Federal Law 2016). The same law states that such organisations have 'the right to receive priority support measures' from the state (Ibid). Thus, in the first half of the 2010s the state in Russia took considerable efforts to differentiate its policies to NGOs, putting obstacles in the way of 'political' NGOs while extending support to those concentrating on social issues.

Against a backdrop of the declining effectiveness of social services in post-Soviet Russia, coupled with resistance to neo-liberal reforms in the population (Bindman 2015:346), SO NGOs began to receive new tax exemptions and access to Federal funding. By the end of Medvedev presidency, SO NGOs increasingly supported the state in the implementation of social policy (Benevolenski, Toepler 2017: 73). From 2014 onwards, state social services were legally obliged to ensure at least $15 \%$ of procurement went to SO NGOs (Tarasenko 2015:351). This new direction would appear to reflect an understanding in government circles on the relationship between the provisioning of social rights and boosting political legitimacy. While, with its neo-liberal reforms, the state would like to spend less and deregulate social policy, it is also sensitive to accusations of abandoning the people and wants to give the impression of being socially responsive to the needs of the population (Bindman 2015:355).

Thus far, two trends in government policy are clear. To summarise recent discussions on the trajectories of the state relations with NGOs, we can link the two-track state policy to NGOs to two discursive tropes: a 'security discourse' and a 'welfare discourse' (Bogdanova et al 2018; Skokova et al 2018:5). On the one hand, in the 'foreign agent' law (Federal Law 2012) and the law on 'undesirable organisations' (Federal Law 2015), repressive legislation aims to curb the activities of NGOs deemed to threaten Russia's internal security (Skokova et al. 2018: 10). On the other, those designated as SO NGOs have access to new funds and close collaborative roles with the state in the implementation of social policy (ibid: 13). The binary state policy between 'potentially dangerous' and 'socially useful' NGOs has resulted in increased division 'between "socially oriented" NGOs and those that work in the field of human rights and environmental protection' (ibid: 10). Here it is worth underlining that, in comparison to political NGOs (10-15\%), SO NGOs make up around $60 \%$ of the total number (Tarasenko 2015). As Meri Kulmala (2011) has pointed out, the scholarly attention to large political NGOs in Moscow is disproportionately large and results in the relative neglect of the work of SO NGOs.

How to evaluate the work of SO NGOs? Some argue that SO NGOs in Russia are little more than 'marionette' organisations subordinated to government policy (Crotty et al. 2014) that are unable to represent their constituencies 
in a dynamic manner. Eleanor Bindman (2015) has reasoned that reforms on social NGOs have put the state in even more influential position with regards to the provision of social services but, on the other hand, significant responsibilities have also been transferred to SO NGOs. Thus, it can be argued the state has turned to SO NGOs to manage a complex and diverse society, as an alternative or companion to top-down methods. On the other hand, new legislation and mechanisms of interaction may have made SO NGOs as much state-orientated as the political NGOs of the 1990s were orientated to private, often foreign, donors. It may well be that SO NGOs are so dependent on servicing the state's needs that they are largely unable to fulfil a meaningful independent role (Kondakov 2017; Kholyavin 2020). Suffice to say that the relationship between the state and SO NGOs is more ambiguous and difficult to characterise than the more clearly hostile relations between the incompatible agendas of human rights NGOs and the Kremlin (Bindman 2015:343).

One could argue that, with these reforms, the Russian government is using SO NGOs to move certain social issues out of the field of 'political contention' into the less-threatening realm of 'social/officially sanctioned contention' (Cheskin, March 2015:262). Thus, instead of viewing Russia as a place where civil society is moribund and the state eliminates those who ignore the informal rules of play, SO NGOs may in some cases enjoy positive, mutually beneficial relations with state bodies (ibid:267) and may well be an effective method for managing social tension in Russia today. In other words, integrating SO NGOs

into social service delivery cannot be considered only as a statist control mechanism but also as a global neo-liberally oriented new public management tool to outsource social responsibilities in the name of cost-effectiveness (Bogdanova et al. 2018:508).

Two considerations arise for those who would test the above interpretations. The first is the diversity of NGOs in Russia. There is considerable difference between those NGOs who behave like 'marionette state-puppets' or 'phantom organisations' fitting no real purpose (Mamonova, Visser 2014) and sovietlegacy organisations that perform rent-seeking actions in resistance to federal neo-liberal reforms. In addition, we can also identify smaller grassroot organisations that refuse to be co-opted by the state, or professional organisations that aim to provide social services in innovative and more efficient ways.

Secondly, there is the issue of regional diversity. Russia's regions differ seriously in a number of areas, including: economic development level, the character of regional political elites and leadership, the openness of the regional regime, the pre-existing size and quality of the NGO network and, finally, the absence or presence of horizontal linking organisations (Toepler et al. 2019). Given these strong regional disparities, there are serious challenges in making broad conclusions about the behaviour of SO NGOs either across Russia as a whole (due to regional diversity), or within a single city (due to dif- 
ferent styles of NGOs). It remains a challenge to uncover where SO NGOs flourish and where they languish, and if so, in which environments.

This article presents the picture of Nizhny Novgorod Oblast and is based on expert interviews conducted from June to December of 2019 involving fifteen experts from three categories: the regional and municipal authorities, entrepreneurs, and representatives of SO NGOs. In the interviews, a special accent was made on interaction of the actors of three types (authorities, entrepreneurs, NGOs) in the field of protection of socio-economic rights of citizens. In this article, we shall primarily focus on how the authorities' practices and attitudes in dealing with the NGOs on the regional level have changed in recent years, as well as outlining directions for further changes from the point of view of the regional authorities.

\section{Forms and directions of institutional change on the regional level}

In terms of the environment for NGOs' activities and the level of the third sector development Nizhny Novgorod oblast appears to be rather average in comparison to other regions. As of the beginning of 2016, the oblast had 250 SO NGOs (Ivashinenko, Varyzgina 2018). However, the statistical data on NGOs in general and SO NGOs in particular is collected both on the federal and the regional level and there numbers do not always match. In August 2019, the federal Ministry of Justice kept records on 3982 NGOs registered in Nizhny Novgorod oblast. On the regional level there is only the data on SO NGOs collected by two institutions, the regional branch of Federal State Statistics Service, and the regional Ministry of Interior, Regional and Municipal Policy. In August 2019 the Federal State Statistics Service reported 1648 NGOs in Nizhny Novgorod region (Ivashinenko et al. 2020).

Analysing expert accounts, several directions of change in the attitudes and practices of the authorities towards NGOs on the regional level can be identified. First, in the last two years the amount of attention and resources given by the authorities to NGOs has seen a dramatic growth. The decision to increase the regional budget spending for NGO support was made on the regional level, but the regional government also relies on the federal funding. The growth rates of expenditures vary from five times (amount of federal grants from the Presidential Fund) to ten times (support for regional NGOs from the oblast budget):

Work with NGOs become increasingly active during three recent years here. Last year the Governor made a decision to increase the support for NGOs ten times... up to fifty million roubles. Plus, we concentrated our efforts at the ministry to work closely with the federal Presidential Grants Fund. Over the last two years, we have received around 100 million a year from the federation (Oblast government ministry top official). 
At least one reason for such an increase is the growing appreciation of the ability of NGOs to fulfil social functions, provide social services for the population in a more accurate fashion and with a softer approach. Moreover, the officials reasonably claim that the state has been dealing for quite a long time now with the delegation of some functions and services, as well as resources, to NGOs. It appears to go without saying for the authorities that certain social services should be transferred to civic organisations from the governmental agencies, which is an indicator of a stable consensus on this question:

Because when we say we involve NGOs for delivering social services, we have to first concentrate on forming a sustainable framework. If we do not do this we will face the fact that there is no one whom we can transfer the services (Oblast government ministry top official).

Thus, parallel to increasing support, the authorities seek to shape the whole sphere of NGOs. Their idea is to create a 'sustainable framework', or a 'reliable core' of the most able socially oriented NGOs. There is no legislation or conceptual document that clarifies organisations eligible to form this 'core'. The organisations suitable for inclusion in the mentioned framework should, from the perspective of the authorities, have certain features which are not formalised yet, but can be partly reconstructed from the analysis of the officials' opinions given in the interviews.

First, they should have a long record of activity, although Soviet-era records are not directly taken into account here. Relevant experience is one key prerequisite to being involved in social services provision in the post-Soviet era. Second, suitable NGOs have to be experienced in dealing with the authorities in the sense of reporting and accounting, especially in the financial sphere. The reason for this requirement is that the authorities, when distributing resources, especially those received from the federal level, seek to secure their own positions in the face of the resource providers. The main point to make here is that the reputation of the regional authorities in the eyes of the federal level should not be put at risk by the performance or accounting failures of the NGOs they have recommended or selected for resource allocation.

Alongside these two rather qualitative features, the authorities in fact employ some quantitative criteria to assess reliability of NGOs. First, they seek to separate 'living' organisations from those simply present in the registries. This can be done by measuring the activities of organisations in participation in grant competitions. It should be noted that the regional authorities use this indicator to assess their own performance as well. As for the second criterion, the authorities mention the number of citizens benefiting from NGOs' activities:

...we see a growing number of non-profit organisations, which take part in all kinds of contests. One of the aims of our programme, the indicator, [is] the growth in numbers of such organisations. Yet another important mark is the number of beneficiaries of their services, and we suppose that every non- 
profit organisation provides a service of some kind (Oblast government ministry top official).

The above-mentioned features refer to reliability of the 'core' NGOs themselves. However, the demand from the authorities with regards to a 'sustainable framework' includes yet another sense, namely, the sustainability of a larger network of NGOs including those that are smaller, less experienced, located outside the regional centres and have less resources. The prevalence of the old soviet-style institutions is characteristic for remote municipalities, according to regional policymakers:

...the oblast centre, here we have the system of NGOs well enough developed, but if we drive 30-40 kilometres away, we can find the 'Society of Invalids', 'Society of the Blind', 'Society of Veterans' and some more scattered civic organisations which do not have any experience of dealing neither with grants, nor with budget money (Oblast government ministry top official).

Considering this, the core NGOs should, in the view of the authorities, become providers of experience, best practices, and even distributors of resources for the smaller and/or less experienced organisations. That is meant to contribute to fail-proof delivery of services to the population, as well as to protect officials from questions related to quality of those services (from the population) and to resource spending (from the federal level or the regulatory authorities).

The issue of citizens questioning the performance of the governmental institutions has been increasingly important in Russia through the recent years. Generally, as discussed in the previous section, the response from the state is usually twofold: silencing the politically-coloured criticism, on the one hand, while developing the mechanisms to deal with the needs of the population, on the other. In case of the Nizhny Novgorod region, a growing awareness and willingness to receive high-quality feedback from the citizens is another sign of institutional change in governmental structures. When it comes to more traditional categories of social service recipients such as the disabled, the necessity of understanding their needs is not only declared, but put into practice. For example, disabled persons are hired for the development of a new regional Internet portal. The portal collects, categorises, and updates information on all available social services for the disabled. In addition, data on the providers of such services is also collected. The ultimate aim of this information gathering is to connect service providers with volunteers.

Another example of the feedback consideration and public involvement into decision making process on the regional level is participatory budgeting. The project of participatory budgeting has been developing in the region since 2013-2014 under the so-called Project for Support of the Local Initiatives (Decree of the Government of Nizhny Novgorod Oblast 2013; Ivashinenko et al. 2020). The procedure includes discussion on the local level concerning the distribution of a certain amount of resources between priority areas. The total 
scope of resources distributed through the participatory budgeting is comprised of those given by the regional budget, the local (municipal) budget, sponsors, and citizens themselves, where the direct financial input from citizens is limited to $3 \%$ of the total. It is claimed by the authorities that the purpose of this participatory budgeting project is not to collect resources from the population, but to enable them to give feedback.

One of the principal elements of the participatory budgeting procedure is the formation of the citizen initiative groups promoting competing proposals for spending such resources. Those groups might be formed in quite an ad-hoc manner, nevertheless, their emergence is welcomed by officials. While it was not directly pointed out by the interviewees, it seems reasonable to suggest that those initiative groups could also be included in the sphere of influence of the core NGOs:

... among the population an initiative group is formed, and it's formed 'bottom-up', we never send anything down. And there are directions on which money can be spent... We artificially limit the population [share] to no more than $3 \%$ of the total sum, because there is no task to collect money from them, what's important is the fact they are ready to give an input (Oblast government ministry top official).

Various institutions are not only being created or projected in a course of the institutional change, but forging links between these institutions is also part of the authorities' agenda. A certain inclination towards network thinking is visible among the authorities: the idea of involving academia in the methodical work of NGOs is received positively by officials:

A: ... it is also important, besides the transfer of the services, to have a certain methodical centre which would correct the list of services and the content of each service, because the main task is to make a person's life better and more comfortable but is seems we now have a more formal approach. Which is a little bit disturbing.

Q: Well, we at the University would be glad to do this $<\ldots>$

A: Well, yes. [We should] think about it more seriously, because a lot of problems we can solve, say, with volunteers (Oblast government ministry top official).

The changing role and growing significance of NGOs are recognised not only by the authorities, but also, directly or indirectly, by the businesses. This recognition has various consequences in the context of the situation in the region. First, the directions of changes sketched by the authorities, match the vision of some existing NGOs involved in the socio-economic sphere. There are NGOs and businesses which support the idea of a sustainable framework of the core NGOs: 'there should be an association with support from government to assemble NGOs of different directions, and further [turn them into] a social movement' (Head of an NGO protecting consumer rights). 
The reason businesses support the empowerment of NGOs is their ability to act as moderators with the authorities, as well as their positive impact on potentially troublesome situations on the lower level, where governmental agencies are frequently not willing to intervene. Due to less formal nature of their job, NGOs can act in the situations where the state agencies are limited with their own regulations. The NGOs can provide the entrepreneurs facing hardship with consultations and assist in paperwork required by the authorities:

I think the state should rely on those organisations, because from within they will form a sort of climate for business... thanks to civic organisations it is possible to stabilise certain situations. When an entrepreneur is on his own with a problem, it's unclear sometimes where to go. And sometimes they [the authorities] wouldn't even listen (Entrepreneur, business NGO representative).

The entrepreneurs give evidence of NGOs involvement in the decisionmaking process, and the authorities correcting their behaviour in response to the NGO's positions and actions:

Civic organisations, they already have access to certain moments. They are already there, their representatives sit in the [advisory] councils and the committees in those offices. They can stand for the interests of entrepreneurs. Now the authorities [may] not directly ask 'How can we do things better?' but may sort of accept opinions from the business community for making better decisions (Entrepreneur, business NGO representative).

The officials' intention to introduce a framework of the core NGOs is matched by similar ideas from the part of entrepreneurs, which acknowledge both the significance of NGOs and the leading role of the state in shaping of the environment for all types of social actors:

I think the initiator of it all should necessarily be the state, the state creates all the infrastructure, the transparent environment where it all is contained. Civic organisations provide significant opportunities for business. They are, above all, unions [who link the state and business] (Entrepreneur, business NGO representative).

It is noteworthy that along with the state efforts to build a rather top-down structure of NGOs (though capable of receiving feedback), there are examples of a reverse approach. In those cases, entrepreneurs and business NGOs initiate communication and collaboration with the authorities, and the latter responds by providing some additional opportunities. Those examples, however, are related mostly to municipal authorities, which are apparently less resourceful than the regional ones, and are struggling to ensure economic development in their municipalities:

We met him [the head of a town district], and he had the idea of bringing manufacturing businesses there with the help from our business community. He said, 'bring us manufacturers and we help with the ground, with 
engineering issues, etc. We need manufacturing here to involve the population, we are ready to prepare specialists for you in our educational institutions' (Entrepreneur, business NGO representative).

Thus, we can conclude that the developments in the attitudes and policies of the Russian state, including their manifestations in Nizhny Novgorod region, have been reshaping significantly over the last five years. After more or less successfully silencing the NGOs involved in acute political issues on the federal level, the state, however, did not remain exclusively in an oppressive role. Instead, state plays the role of resource provider and architect, managing the terms of a new environment for NGOs. As will be seen below, it is not accurate to see the state as either an agent of total control nor an unobtrusive arbiter. With 'problematic' political NGOs being side-lined, social NGOs are cultivated as allies or auxiliaries of the state that can deliver key services and open up a channel of communication between the state and the population.

\section{Problems of Institutional Change}

The new state approach is important and promising, but it is not free from shortcomings. Despite the changes, the state's attitude towards NGOs remains somewhat ambiguous. The desired sustainable framework of the socially responsible and able NGOs discussed above is expected to appear only in the next three to five years. NGOs are recognised as an inevitable part of society, which calls for dialogue rather than suppression. Nonetheless, NGOs are still seen as a potential source of trouble. It is peculiar how in the following fragment the expert restrains himself from a clear formulation of the potential threat, whether undesired political activity or financial misconduct. Based on the rest of the interview, however, particularly on the fragments considering the desired features of the most reliable core NGOs, it can be suggested that undesirable behaviour mentioned is about accounting and reporting failures rather than political criticism or opposition activism:

We have fourteen priority directions for which we give subsidies, but we would like to also try it with some NGOs, on a competitive base, to make them resource centres, to make them the distributors of the money. We may try this, but one needs to be very careful here to avoid... you know what (Oblast government ministry official).

Alongside with quality problems, officials mentioned some quantity issues which pose problems for developing a successful system of SO NGOs in the region. One of them is simply the insufficient number of NGOs, particularly, the socially oriented ones. Assessing the number as insufficient for the region, the authorities, nevertheless, clearly reject the approach taken, according to their words, in some other regions, where some state or municipal, or even business institutions have been re-opened as NGOs to fulfil the demand of the federal 
centre to increase the number of NGOs providing social services: 'I don't want to follow the path... I don't need those organisations newly made "from above" for solving some auxiliary problems' (Oblast ministry top official).

An additional aspect of the numerical deficiency of NGOs in the oblast is their uneven distribution between the regional centre and smaller towns and rural settlements. The NGOs are concentrated mostly in Nizhny Novgorod and in other relatively big cities and towns. The authorities now reflect on two ways of increasing the number of NGOs across the region. One of them is to attract federal resources (grants) to the formation of reliable new types of NGOs in the distant districts of the oblast. The other is to set up a resource centre in Nizhny Novgorod that is meant to provide methodological support and to mentor local NGOs in distant localities. So far, such help is provided by the governmental administrators themselves, which is considered to be insufficient because of a shortage of staff dealing with NGOs issues.

The lack of staff in the governmental bodies is yet another quantity-related issue. The serious increase of the money flow to be distributed among the NGOs was not met by a corresponding growth of the personnel, because, obviously, money is a much more liquid resource than jobs in the government sector. The regional ministry does not have enough staff to manage the growing amount of resources:

The flow [of money] increased ten times, the quantity of people didn't. We searched the statistics of other regions. Well, the most illustrative one is, of course, the Khanty-Mansi autonomous okrug. What they have is a fairy tale. They spend 100 million roubles on NGOs, and there are 25 staff members. Can you imagine? Sure, they can easily administer a whole bunch of projects. And we are begging for six staff members to administer the sum of fifty million (Oblast ministry top official).

The problematic aspects of the situation are located not only on the regional level itself. It is acknowledged by the regional authorities themselves that the quality level of some federal normative acts is insufficient since they do not have rules on feedback and communication with citizens. One of the respondents elaborated on this using the example of the so-called 'waste reform', i.e. the new regulations for household waste utilisation. According to those regulations, the waste is to be utilised by companies selected on a competitive basis. In practice, however, those companies are non-transparent and non-responsive to the population:

Not a single federal normative document has a description of communication norms. If [the waste utilisation operators] could have their own websites with feedback features, phone lines with enough capacities to let everyone get through. If they had a legal obligation to have a representative in each municipal district with whom people could talk directly, there would be ten times less fuss and unrest among the population (Oblast government ministry top official). 
There is also a certain communicative mismatch between the government and NGOs. In the view of the administrative officials, that should be remedied by teaching the NGOs to comply with the standards (mainly those of accounting and financial reporting) similar to those used by the administrators themselves. The idea is to make the NGO activists 'a little bit more like bureaucrats', however, at the moment it is not perceived as fully realistic:

We generally have lots of people with shining eyes, who are enthusiastic about their ideas, but it's hard to make them a little bit more like bureaucrats as well, because by their nature they are much more emotionally involved (Oblast government ministry top official).

Considering specifically the possible mechanisms of public participation in promoting business competition, we should conclude that they are still unclear, though have been a subject of discussion for some time already. The most evident approach of the public involvement seems to be the involvement of citizens as consumers. However, the government officials argue that one of the most significant problems here is the lack of expertise among the population, even in the role of consumers. Their argument is that consumers' opinion is highly volatile and unstable. Some officials report that there has been a search for an adequate method for screening consumer opinion, although this has not yet been found.

An adequate approach would require a rather sophisticated composition of public opinion screening technologies, including phone polls with the help of call centres, online polls, etc. Neither the governmental offices themselves, nor the state-associated agencies for consumer rights protection have enough resources to perform such activities. Besides resource limitations, they are also over-regulated in respect to the types of activities they can legally perform. The NGOs seem to be a reasonable alternative here as collectors of and speakers for public opinion, but the officials insist that such NGOs should first earn their own reputation and trustworthiness:

Only in one case can those NGOs decide, when they are truly professional, because to solve a [social] problem, [this is what] it takes... NGOs don't have any standards of quality... they should have a certain standard of trustworthiness. Otherwise, their decisions and estimations are not needed for anyone. So, if we make our decisions through an NGO, it must be proven that it's professional and trusted (Oblast government ministry top official).

Discussing the problematic aspects of changes in the state institutions collaborating with the NGOs we should look at those changes from the perspective of the NGOs as well. Most of the changes within the state are generated by the state itself, but often they affect the associated NGOs. The transfer of services provision from the state to NGOs sometimes leads to overload of NGOs with duties. In some areas, the state drops its former functions (willingly or unwillingly) so rapidly that NGOs have to do much more work than they used to. An illustrative example here is the sphere of consumer rights 
protection. The reduction of staff in the municipalities led not only to the termination of services by the municipal authorities on a certain level (municipal districts), but also to the inability of those authorities to involve the NGOs which could possibly renew the services:

A: We have the state standard of service in consumers' rights protection. But there's not a single specialist in the district administrations, they were all fired. And NGOs are not involved. We have a lot of consumer protection organisations in Nizhny Novgorod.

Q: What if those organisations take the initiative?

A: They will not be accepted. And it looks like Rospotrebnadzor [the federal agency for consumers' rights protection with branches in every federal subject] is not really interested in this. They even shut the advisory council under the Governor (Head of an NGO protecting consumers' rights).

It should be noted that the criticism here is addressed mostly to the municipal level. The relations between the state (including the federal and the regional level) and the municipal level, especially in respect to distribution of resources, authorities, and responsibilities constitute a separate problem, the consideration of which is beyond the scope of this article. We believe, however, that this issue is still illustrative, for the municipal level shares the same problems as the regional one, only with less resources and capabilities:

Q: So, it turns out that only the NGOs are responsible for that?

A: Yes. There is no one else. Rospotrebnadzor and NGOs.

Q: And which of them is going to provide effective assistance to people?

A: The NGOs, of course. Rospotrebnadzor is overloaded and has no time. As far as I know, now in the whole department for consumes rights protection they have only twelve people (Head of an NGO protecting consumers' rights).

Thus, although the paradigm of the state-NGOs relations has been changing in the recent years, the new mode of their relations has not yet stabilised, and numerous problems remain. The problems concentrate mostly in the sphere of communicative protocols and interfaces between the state and NGOs, and in the sphere of resource distribution, both in quantitative and qualitative sense. The aspect of shared values seems to be less problematic (at least in the case of Nizhny Novgorod region) although some residuals of mutual uncertainty and suspiciousness remain.

\section{Conclusion}

Relations between the state and the NGOs in Russia have moved through several stages, of which the current one seems to give hope for mutually beneficial developments at least in some spheres. For the state, the central idea of 
the current stage was to involve the socially oriented NGOs in the implementation of social policy, while offering in exchange patronage and resources. A certain shift of values has occurred within the state, and NGOs (at least, some of them) have been recognised as 'socially oriented', responsible, and able agents of social policy.

Institutionally, this meant the changes in the role models and norms of relations between the two sides. The state did not take on an exclusively repressive role. Instead, it assumed a new set of roles, such as resource provider and architect, planning and building the new environment for NGOs. The state now, to a great extent, is neither a non-intrusive observer, nor a dictator or total oppressor, but a top-down initiator and supporter of activities. At the same time, the state tends to stratify NGOs and, dependant on their positions in this stratification, offers some of them new roles, such as mentors for other NGOs, resource distributors and providers.

This new model of relations, envisioned by the state, is not yet stable and free of problems. At this stage the most visible problems revolve around a lack of mutual understanding on the operational level, deficiencies in 'social interfaces', and a sometimes-unequal redistribution of resources and responsibilities. At the same time, this model leaves those NGOs not fitting into the vision of 'socially oriented' and/or 'reliable' outside state patronage and potentially subject to further restrictions.

\section{References}

Benevolenski V.B., Toepler S. (2017) Modernising Social Service Delivery in Russia: Evolving Government Support for Non-profit Organisations. Development in Practice, 27 (1): 64-76.

Bindman E. (2015) The State, Civil Society and Social Rights in Contemporary Russia. East European Politics, 31 (3): 342-360.

Bogdanova E., Cook L. J., Kulmala M. (2018) The Carrot or the Stick? Constraints and Opportunities of Russia's CSO Policy. Europe-Asia Studies, 70 (4):501-513.

Cheskin A., March L. (2015) State-society Relations in Contemporary Russia: New Forms of Political and Social Contention. East European Politics, 31 (3):261-273.

Crotty J., Hall S. M., Ljubownikow S. (2014) Post-Soviet Civil Society Development in the Russian Federation: The Impact of the NGO Law. Europe-Asia Studies, 66 (8): 1253-1269.

Decree of the Government of Nizhny Novgorod Oblast (2013) O realizatsii na territorii Nizhegorodskou oblasti pilotnogo proekta po podderzhke mestnykh inittsiativ [On the Realisation of the Pilot Project Supporting Local Initiatives on the Territory of Nizhny Novgorod Oblast], No 97 from 21.02.2013.

Federal Law (2006) O vnesenii izmenenii v nekotorye zakonodatel'nye akty Rossiiskoi Federatsii [On Amending Certain Federal Laws of Russian Federation] No 18-FZ from 10.01.2006. 
Federal Law (2010) O vnesenii izmeneniy v otdel'nyye zakonodatel'nyye akty Rossiyskoy Federatsii po voprosu podderzhki sotsial'no oriyentirovannykh nekommercheskikh organizatsiy [On Amending Certain Legislative Acts of the Russian Federation on the Support of Socially-Oriented Non-Profit Organisations] No 40-FZ from 5.04.2010.

Federal Law (2012) O vnesenii izmenenii v otdel'nye zakonodatel'nye akty Rossiiskoi Federatsii $v$ chasti regulirovaniya deyatel'nosti nekommercheskikh organizatsii, vypolnyayushchikh funktsii inostrannogo agenta [On Amending Certain Federal Laws Regarding Regulation of Activities of Non-profit Organisations Performing Functions of Foreign Agents], No 121-FZ from 20.07.2012.

Federal Law (2015) O vnesenii izmenenii v otdel'nye zakonodatel'nye akty Rossiiskoi Federatsii [On Amending Certain Legislative Acts of Russian Federation] No 129-FZ from 23.05.2015.

Federal Law (2016) O vnesenii izmeneniy v Federal'nyy zakon 'O nekommercheskikh organizatsiyakh' $v$ chasti ustanovleniya statusa nekommercheskoy organizatsii-ispolnitelya obshchestvenno poleznykh uslug [On Amendments to the Federal Law 'On Non-Profit Organisations' in Terms of Establishing the Status of a Non-profit Organisation- A Performer of Publicly Useful Services] No 287-FZ from 3.07.2016.

Hemment J. (2012) Nashi, Youth Voluntarism, and Potemkin NGOs: Making Sense of Civil Society in Post-Soviet Russia. Slavic Review, 71 (2): 234-260.

Holavins A. (2020) Otnosheniye k chayepitiyu kak marker professionalizatsii soobshchestva tret'yego sektora v Sankt-Peterburge [Attitude to Tea Drinking as a Marker of the Professionalization of the Third Sector Community in St. Petersburg]. Zhurnal Issledovanii Sotsial'noi Politiki [The Journal of Social Policy Studies], 18 (1): 99-114.

Ivashinenko N., Varyzgina A. (2018) Socially Oriented NGOs and Local Communities in a Russian Region: Ways to Build Up Their Relationship. Laboratorium: Russian Review of Social Research, 9 (3): 82-103.

Ivashinenko N. N., Varyzgina A. A., Soldatkin A.E. (2020) The Role of NPOs in the Socio-Economic Development in the Russian Region. Advances in Economics. In: Proceedings of the International Scientific Conference 'Far East Con' (ISCFEC 2020). Business and Management Research, (128): 2917-2935.

Kondakov A. (2017) Queer Coalitions: An Examination of Political Resistance to the Russian Migration Law. Europe-Asia Studies, 69 (8): 1222-1241.

Kulmala M. (2011) Rethinking State-Society Boundaries in a Small-Town Context of Russian Karelia. In: M. Jappinen, M. Kulmala, A. Saarinen (eds.) Gazing at Welfare, Gender and Agency in Post-Socialist Countries. Newcastle upon Tyne: Cambridge Scholars Publishing: 170-198.

Ljubownikow S., Crotty J. (2013) Civil Society in a Transitional Context. Nonprofit and Voluntary Sector Quarterly, 43 (4): 759-776.

Mamonova N., Visser O. (2014) State Marionettes, Phantomorganisations or Genuine Movements? The Paradoxical Emergence of Rural Social Movements in Post-Socialist Russia. The Journal of Peasant Studies, 41 (4): 491-516.

Puffer S. M., McCarthy D. J. Jaeger A. M. (2016) Institution Building and Institutional Voids. International Journal of Emerging Markets, 11 (1): 18-41. 
Sätre A. M. (2014) Paid and Unpaid Social Work in Russia: Is Women's Social Work Opening up Opportunities for Empowerment Processes? International Social Work, 57 (5): 523-534.

Skokova Y., Pape U., Krasnopolskaya I. (2018) The Non-profit Sector in Today's Russia: Between Confrontation and Co-optation. Europe-Asia Studies, (4):531-563.

Sundstrom L. M., Henry L. (2006) Russian Civil Society: Tensions and Trajectories. In: A. Evans, L. Henry, L. M. Sundstrom (eds.) Russian Civil Society: A Critical Assessment. London: Sharpe: 305-322.

Tarasenko A. (2015) Russian Welfare Reform and Social NGOs: Strategies for Claim-Making and Service Provision in the Case of Saint Petersburg. East European Politics, 31 (3): 294-313.

Toepler S., Pape U., Benevolenski V. (2019) Subnational Variations in Government-Nonprofit Relations: A Comparative Analysis of Regional Differenceswithin Russia. Journal of Comparative Policy Analysis: Research and Practice, (1): 47-65. 